\title{
John Calvin and John Locke on the Sensus Divinitatis and Innatism
}

\section{J. Caleb Clanton}

Department of History, Politics, \& Philosophy, Lipscomb University, One University Park Drive, Nashville, TN 37204, USA; caleb.clanton@lipscomb.edu; Tel.: +1-615-966-5727

Academic Editor: Christopher Metress

Received: 4 December 2016; Accepted: 13 February 2017; Published: 20 February 2017

\begin{abstract}
Inheritors of the Calvinist Reformed tradition have long disagreed about whether knowledge of God's nature and existence can be or need be acquired inferentially by means of the standard arguments of natural theology. Nonetheless, they have traditionally coalesced around the thought that some sense or awareness of God is naturally implanted or innate in human beings. A root of this orientation can be found in John Calvin's discussion of the sensus divinitatis in the first book of The Institutes of the Christian Religion. This paper outlines a pedagogical strategy for organizing and evaluating Calvin's treatment of the sensus divinitatis, chiefly by putting it in tension with John Locke's polemic against innatism in Book I of An Essay concerning Human Understanding. I begin by reconstructing Calvin's depiction of the sensus divinitatis, as well as his case for thinking that it is innate. I then explain how Locke's critique of innatism offers a fairly direct response to Calvin and, hence, a useful framework for exploring the limits of Calvin's treatment of the sensus divinitatis.
\end{abstract}

Keywords: Calvin; sensus divinitatis; natural theology; Locke; innatism; innate ideas

\section{Introduction}

Suppose there is such a person as God. Should we assume that we could come to know about this God without recourse to something like scriptural revelation or direct revelatory experiences? Would the kinds of philosophical arguments that, say, St. Thomas Aquinas offers be adequate to the task? More generally, would supernaturally unaided human reasoning ever be capable of leading us to knowledge of God's nature and existence?

The unease that many inheritors of the Calvinist Reformed tradition have expressed in attending to these sorts of questions is epitomized in some ways in the bitter punch-up between Karl Barth and Emil Brunner in the 1930s. In light of Brunner's call for his generation of theologians to "find the way back to a true theologia naturalis," even the one-word title of the essay Barth wrote in response to Brunner echoes the anxiety that some Reformed thinkers continue to feel: "Nien!" ([1], p. 59). And while a continuous thread of Reformed thinkers has endorsed some form of natural theology since as far back as the early sixteenth century ([2], pp. 9-40), Nicholas Wolterstorff has claimed recently that a revulsion against theistic arguments has been "characteristic of the Continental Calvinist tradition" ([3], p. 7). Along similar lines, Alvin Plantinga has said that, "for the most part," the Reformed attitude toward proving God's existence "looks a little like the attitude some Christians adopt towards faith healing: it can't be done, but even if it could, it shouldn't be" ([4], p. 49).

Though Reformed thinkers have long disagreed about whether knowledge of God's nature and existence can be or need be acquired inferentially, they have nonetheless traditionally coalesced around the thought that some sense or awareness of God is naturally implanted or innate in human beings-that we have some sort of cognitio Dei insita, even if we do not or cannot have cognitio Dei acquisita ([2], p. 57; [5], pp. 42-43; [6], pp. 95-104). A root of this orientation can be found in John Calvin's discussion of the 
sensus divinitatis in the opening book of The Institutes of the Christian Religion. Because that discussion comprises one the most influential contributions to the development of Protestant theology-and hence to the last five centuries of Western history-it is certainly fitting for college professors to cover it in their general education courses, as well as in other undergraduate theology, philosophy, history, and humanities courses.

The purpose of this paper is to outline a way of organizing and evaluating Calvin's treatment of the naturally implanted awareness of God, chiefly by putting it in tension with John Locke's famous polemic against innatism in Book I of An Essay concerning Human Understanding. My intention is not so much to proffer specific techniques of classroom delivery as it is to sketch a way of approaching the ideas to which the texts in question give rise. Suffice it to say that I trust that my approach to reading Calvin and Locke in tandem will have meaningful applications in a variety of undergraduate courses. For example, philosophy professors might find it worthwhile to use Calvin as an alternative way of motivating one of the central debates of the modern period between rationalists and empiricists. Of course, the standard way of discussing Locke's empiricism these days is by positioning Descartes as the rationalist foil. But undergraduates often fail to see what is at stake when the matter is presented in this way; hence they often find much of Locke's Essay unmotivated and, frankly, boring. Happily, Calvin's innatism, when read in combination with Locke, can help students-especially religious students-see what hangs in the balance. Or, to take another example, religion professors might use this side-by-side reading of Calvin and Locke as a historically informed way of wrestling with questions related to the proper grounding of religious faith-Do we need to rely on arguments, or is it something else at play? And, more generally, humanities and core texts professors can use this approach as an entry point into some of the great canonical texts of the Reformation and modern period.

The paper proceeds as follows. I begin by reconstructing Calvin's depiction of the sensus divinitatis (§2), as well as his case for thinking that it is innate (§3). I then explain how Locke's critique of innatism offers a fairly direct way of engaging with Calvin's ideas and, hence, a helpful way of motivating students' interest in either thinker's views $(\$ 4)$. Of course, this way of setting things up should not be taken to imply that Locke took himself to be responding directly to Calvin. But my contention is that reading Calvin in tension with Locke helps shed light on both thinkers, as it provides a useful framework for undergraduates to explore the limits of Calvin's treatment of the sensus divinitatis, as well as the limits of Locke's rejection of innatism (\$5). And not only does this approach have the historical pay-off of introducing students to two of the most towering Protestant figures of the Christian intellectual tradition, but it also sets the stage for a philosophical and theological inquiry of ongoing significance. Are we born blank slates, for example, and are all the contents of our minds derived of some sort of prior experience? Can we have knowledge of God's existence, and if so, by what means? Can belief in God be properly basic? How should we interpret key passages in Romans 1 and 2? And so on.

Before moving on, let me say what I think is a reasonably manageable reading assignment for undergraduates related to the issues discussed herein. I would recommend that students read chapters 1-6 of Book I of Calvin's Institutes, as well as chapters 2 and 4 of Book I of Locke's Essay, distributed over two class periods. For greater theological context, one might also find it helpful to assign Romans 1 and 2, as well as the relevant sections in Calvin's and Locke's respective commentaries on Romans ([7], pp. 46-52, 72-75; [8], pp. 280-98).

I turn now to Calvin.

\section{Calvin on the Sensus Divinitatis}

Chapter 3 of Book I of Calvin's Institutes opens with these words: "That there exists in the human minds and indeed by natural instinct, some sense of Deity, we hold to be beyond dispute" ([9], I.iii.1). Now, it is worth stressing to students that there are two distinct claims on offer here. The first is that human minds possess a sense of Deity (or, what one translator renders as an "awareness of 
divinity" ([10], I.iii.1). The second claim is that we possess this sense or awareness innately. We should pause here to consider each of these assertions separately.

First off, what exactly is this thing that Calvin thinks we possess-suppose we call it the "sensus" for short? To be sure, he depicts it in various ways. On one pass, for example, he characterizes it as a divinely instilled "idea of the Godhead, the memory of which he [God] constantly renews and occasionally enlarges" ([9], I.iii.1; emphasis added). On another pass, he describes the sensus as an awareness that "that there is a God, and that he is their Maker" ([9], I.iii.1). Along similar lines, he depicts it as a "common conviction possessed by the mind" (specifically the "conviction that there is a God"), as a "sense of religion," and as an "impression of a Deity" ([9], I.iii.1; emphases added). Still further, he characterizes the sensus as "that uniform belief in God" with which we are imbued as though with a "seed" from which the "religious propensity springs" ([9], I.iii.2; emphasis added). He additionally describes the sensus as the "remembrance of God" that is "spontaneously suggested" to the human mind "from within, by a natural sense" ([9], I.iv.2; emphasis added).

That the sensus is innate to the human mind-and that it is innate precisely because God put it there-is the second claim Calvin regards as indisputable. He writes, for example, that the sensus is "thoroughly fixed...in our very bones" ([9], I.iii.3) — that it is "stamped on the breast of all men," and "inscribed on every heart" ([9], I.iii.1) —and he depicts it as an idea of God that "always exists in every human mind" ([9], I.iii.2). The sensus is, he says, "indelibly engraven on the human heart" and "naturally engendered in all ([9], I.iii.3). And even more to the point at hand, he contends that the sensus is "not a doctrine which is first learned at school, but one as to which every man is, from the womb, his own master" ([9], I.iii.3). In other words, the sensus is not something we acquire by, say, inferring it from something even more basic and naturally knowable to human minds. Rather, the sensus is, as it were, always already nonderivatively in the mind as a "seed of divine knowledge so wondrously deposited" by God ab initio ([9], I.v.15).

In connection to that last point, it can be helpful for students to know that a number of scholars contend that Calvin's depiction of an innate sensus resembles, and was plausibly derived of, the Epicurean and Stoic notion of a prolepsis (or, preconception) of God, particularly as it appears in Cicero's De Natura Deorum ([11], pp. 284-85; [12], p. 96; [13]). What, exactly, is a prolepsis? Edward Adams explains that, for Stoics and Epicureans, a prolepsis was thought to be an innate, commonly possessed "basic notion which arises naturally without mental effort or instruction," the truth of which can be "taken for granted" without the need for argument and which can function as the measure against which other propositions are judged ([11], p. 285). Accordingly, in Adams's view, "For Calvin, the sensus divinitatis is a 'preconception' [=prolepsis] of God in line with the Stoic theory" ([11], p. 285). This plausibly Ciceronian dimension of Calvin's sensus will be significant for reasons that will become apparent below.

For now, though, we might wonder why, in Calvin's view, the sensus would need to be innate in the first place, as opposed to being acquired inferentially. He offers at least three reasons. First, the innateness of the sensus is sufficient "to prevent any man from pretending ignorance" of God's existence and, hence, of one's obligation to worship God ([9], I.iii.1). Obviously enough, if one were non-culpably unaware of God's existence, then one would have a legitimate excuse for not believing in or worshipping God. However, an innate possession of the sensus would indeed foreclose even the possibility of such an excuse, an excuse which we lack according to Romans 1:20. A second and related purpose for which the sensus is innate is so that "all to a man...may be condemned by their own conscience when they neither worship him [God] nor consecrate their lives to his service" ([9], I.iii.1). The thought here is that, if everyone had an innate sense of God, then they would be convicted as though from within of their own shortcomings with respect to God. This is presumably a nod to the Apostle Paul's mention in Romans 2:14-15 of an accusatory law written on the human heart.

There is, I think, yet a third reason for the innateness of the sensus in Calvin's view. Despite the fact that he never makes this point explicit in the Institutes, it is nonetheless clear from his Commentary on Romans that Calvin thinks the innateness of the sensus is also consistent with, if not simply an 
elaboration of, Paul's words in Romans 1:19. To see the point in high relief, it is helpful to keep in mind that English translations of this passage typically vary between saying that what is knowable about God is either "plain to humans" (e.g., NRSV) or "manifest in humans" (e.g., KJV). The preposition here-to or in-appears to be significant for Calvin, since he seems to think that it speaks to the means by which God would be knowable - whether inferentially or non-inferentially, for example-and, hence, whether there would be a need for something like an innate sensus in the first place. He writes, for example:

Insane then are all they who seek to know of themselves what God is: for the Spirit, the teacher of perfect wisdom, does not in vain invite our attention to what may be known...and by what means this is known, he immediately explains. And he said, in them rather than to them, for the sake of greater emphasis...he seems here to have intended to indicate a manifestation, by which they might be so closely pressed, that they could not evade; for every one of us undoubtedly finds it to be engraven on his own heart ([7], p. 48; emphases added).

The take-away point here is that, as Calvin reads Paul, what is knowable about God is manifest in us, as opposed to being shown to us. And Calvin apparently takes this to mean that something like the sensus is implanted in humans-engraven on our hearts as the unmerited gift of God-as opposed to being something that is acquired through the efforts of the human endeavor-say, by reasoning about the evidence shown to us.

\section{Calvin's Argument for the Innateness of the Sensus}

Students are right to wonder why we should think that humans possess such a sensus, and-more to the point at hand-why we should think that we possess it innately. So the natural question is to ask at this juncture is: What reasons does Calvin marshal in support of those claims?

His reasoning on the matter can be organized into a two-step argument. First, he argues that the sensus is, in fact, universally possessed by everyone-a claim for which he offers several supporting considerations and defenses. And, second, he contends that the universality of the sensus implies its innateness. Accordingly, his argument-what we might dub Calvin's argument from universal possession—can be rationally reconstructed as follows:

(C1) Every human possesses [a] an idea of God and [b] some sort of sense/awareness/ conviction/belief that there is a God. [=universality thesis]

(C2) If [a] and [b] are universally possessed, then [a] and [b] are innate. [=implication thesis]

(C3) Thus, [a] and [b] are innate. [from C1 and C2]

(C4) Thus, every human possesses [a] and [b] innately. [from C1 and C3]

Calvin's case for premise $\mathrm{C} 1$ is not to claim that it is known through reason a priori, or even through scriptural revelation ([12], p. 95). Rather, his case appears to be a combination of empirical observation and inductive generalization. He claims, for example, that "experience testifies that a seed of religion is divinely sown in all" ([9], I.iv.1; emphases added). The thought here, presumably, could be fleshed out as follows: All observed humans exhibit, in some form or fashion, the possession of the sensus in question. Moreover, there are no genuine exceptions to this observation, even among those whom we might most expect to find exceptions—viz., those among "the dullest tribes farthest removed from civilization" and those who "seem to differ least from the lower animals" ([9], I.iii.1). Nor would idol-worship and other superstitious practices count as legitimate counterexamples. In fact, Calvin regards those practices as even further evidence in support of the universality thesis, the thought being that they simply represent a perversion of the sensus, and, as one commentator says, "it is impossible to pervert what does not exist" ([12], p. 95). So, in an apparent nod to Cicero ([14], I.xvi), Calvin asserts that "there is no nation so barbarous, no race so brutish, as not to be imbued with the conviction that there is a God" ([9], I.iii.1). Accordingly, the bottom line for Calvin seems to be that, in the absence of counterexamples, we can simply generalize from our everyday observations to premise $\mathrm{C} 1$. 
Now, we should note that, in addition to the universality thesis, something like the implication thesis would be needed to get from $\mathrm{C} 1$ to $\mathrm{C} 3$ and $\mathrm{C} 4$. Without it, for example, Calvin would have nothing to offset the worry that a uniform sense of God could emerge as, say, a product of human convention or chance or, at any rate, something other than God's design (such that the uniform sense in question would ultimately be unreliable). And, indeed, Calvin appears to assume something like premise $\mathrm{C} 2$ as a given. He asserts, for example: "Since, then, there has never been, from the very first, any quarter of the globe, any city, any household even, without religion, this amounts to a tacit confession, that a sense of Deity is inscribed on every heart" ([9], I.iii.1; emphasis added). Additionally, he goes on to say toward the close of the same chapter that, in light of the fact that "some idea of God always exists in every human mind.... All men of sound judgment will therefore hold, that a sense of Deity is indelibly engraven on the human heart" ([9], I.iii.2-3). The gist here appears to be that the universal possession of the sensus implies, or is at least best explained by, its innateness; hence, premise C2.

Unfortunately, though, Calvin is less than fully transparent about what he regards as warrant for the implication thesis of premise $\mathrm{C} 2$, despite the fact that he assumes it-and needs to assume it—all the same. In light of the context of the passages cited above, one conjecture is that Calvin may have simply borrowed the thought from Cicero. Cicero held, for example, that

since their [the gods'] existence is pretty universally admitted not only among philosophers but also among those who are not philosophers, let us own that the following fact is also generally allowed, namely, that we possess a 'preconception,' ...or 'previous notion' of the gods ([14], I.xvii).

Apparently, Cicero regarded the universal acceptance of a proposition as some sort of indication that we also possess an innate prolepsis of the concepts that comprise the proposition in question. And if Calvin is as indebted to Cicero's work on these matters as some scholars have suggested, then we have at least a plausible account of what may have inspired Calvin to hold premise $\mathrm{C} 2$, even if we are still in the dark as to what is supposed to warrant that assumption.

Leave that particular concern to the side for now. Calvin tries to defend his overall case for the universal possession and innateness of the sensus against two different objections. The first objection is the charge that "religion was devised by the cunning of a few individuals" as a means of manipulating society ([9], I.iii.2). We might think of this as something of a proto-Marxist objection: religion is a kind of manufactured opium for the masses, peddled by a pushy pusher. The critic's thought here would be that, since religion is nothing more than a manipulative fiction, the universality thesis is clearly false (the pushers themselves would obviously be exceptions to premise C1), and the implication thesis is false as well (universality would be achieved through widespread deception, not innateness).

Calvin's concedes that perhaps "designing men" have indeed introduced falsehoods into religion, but he thinks that the efficacy of religious fictions in manipulating the masses actually neutralizes the objection at hand ([9], I.iii.2). Why is this? In short, Calvin thinks that the masses would not be so easily manipulated by religion if something like the sensus were not already operating in the background. Presumably, one cannot use for manipulation what is not present to manipulate, and given that the masses are so easily wrought by religion, Calvin thinks we have even further evidence in support of the universal possession of the sensus. Hence he claims, for example, that the designing men in question "could never have succeeded in this [manipulation] had the minds of men not been previously imbued with that uniform belief in God, from which, as from its seed, religious propensity springs" ([9], I.iii.2).

The second objection Calvin considers is the charge that, contra premise $\mathrm{C} 1$, there are those who simply lack an awareness of God ([9], I.iii.2). Opponents of premise C1 will of course point to various nonbelievers throughout history. Still, while Calvin concedes that there are individuals who "deny the being of a God," he contends that even those folks will, from time to time, encounter an awareness of God, whether they want to or not ([9], I.iii.2). "Though the conviction may occasionally seem to vanish for a moment," Calvin writes, "it immediately returns and rushes in with new impetuosity" under certain circumstances ([9], I.iii.2). There are, in other words, no thoroughgoing atheists in the foxholes 
of life. What evidence does he offer in support of this kind of view? In effect, he tells us to take a look at what happens to the tough when the tough really gets going. He writes: "When at their ease, they [the reprobate] can jest about God, and talk pertly and loquaciously in disparagement of his power; but should despair, from any cause, overtake them, it will stimulate them to seek him, and dictate ejaculatory prayers, proving that they were not entirely ignorant of God but had perversely suppressed feelings which ought to have been earlier manifested" ([9], I.iv.4; emphasis added). Apparently, in other words, those ejaculatory prayers, amount to telltale evidence that the folks in question were not, in fact, unaware of God all along.

\section{Locke's Polemic against Innatism}

Students will naturally wonder about how successful Calvin's argument from universal possession is? Is it plausible to think that humans possess a sense of God innately? It is here, I think, where it helps to have undergraduates consider Locke's critique of innatism as a way of critically engaging with Calvin. So I turn now to Locke.

According to Nicholas Jolley, the impetus behind Locke's attack on innatism was not only the desire to correct philosophical error, but also "the desire to expose a threat to the open society" ([15], p. 32). Locke's worry, Jolley claims, was that the doctrine of innatism "serves as an excuse for removing classes of propositions from the sphere of rational scrutiny" and, hence, that innatism "plays into the hands of those of an authoritarian cast of mind" ([15], p. 32). Assuming Jolley is correct, then, we might say that Locke challenged innatism in part because he regarded it as the tool of tyrants, dogmatic moralists, and demagogic pulpiteers. And although Locke rejected all forms of innatism, it is easy enough to imagine that, given just how frequently innatism was invoked vis-à-vis religion in his day, Locke probably had religious iterations of innatism in his sights ([16], p. 1991).

Now, admittedly, it might at first seem strange—if not simply anachronistic — to turn to Locke when thinking specifically about Calvin, especially in light of the fact that scholars virtually never discuss them in tandem with respect to the sensus, for example ${ }^{2}$. But I think this is nonetheless a sensible thing to do, for at least three reasons. First off, the link between Locke and Calvin on these matters is far less surprising than one might suspect on first glance. While Locke does not make explicit in the Essay which advocates of innatism he means to be attacking, scholars typically see him as taking aim at such seventeenth century thinkers as Descartes and the Cambridge Platonists, as well the Anglican Bishop of Worchester, Edward Stillingfleet ([16], pp. 200-2; [18], p. 46; [19], pp. 35-43). The Stillingfleet connection in particular is worth highlighting here. In a work with which Locke was clearly very familiar (viz. Stillingfleet's Origines Sacrae [1662]), Stillingfleet pulls explicitly from Cicero's discussion of the prolepsis of God, as well as Cicero's so-called argument from universal consent, in formulating his own case for the existence of God ([19], pp. 37-38). And, as noted above, there are solid reasons for thinking that Calvin was also influenced by Cicero's discussion of the prolepsis of God as well. Thus, to the extent that the residue of Cicero can be found in both Stillingfleet and Calvin, and given that Locke was almost certainly taking aim at the Stillingfleet's Ciceronian variety of innatism, it is actually not that surprising on final analysis that Locke's polemic against innatism would connect up as neatly in response to Calvin as I believe it does. Second, and more important, even if Calvin's Institutes was the furthest thing from Locke's mind when he penned the Essay, his polemic against innatism is certainly no less logically relevant to an evaluation of Calvin's views on the sensus. Plainly enough, if Locke is right to reject innatism, then Calvin's account of the sensus-together with those elements of his theology that are parasitic on it-is clearly problematized to the extent that it presupposes a refuted brand of innatism. And, third, as I have already indicated, there is certainly pedagogical value to reading Locke and Calvin together, in part because doing so helps put important

1 For more on the relevant theological context surrounding Locke's discussion of innatism, see [17].

For the only notable exception that I am aware of, see [12], which I discuss below. 
epistemological and theological issues in plain view-and in a way that introduces undergraduates to two of the most important figures in Western history.

Locke's critique of innatism can be organized into two broad stages ${ }^{3}$. He first offers a series of objections aimed at undercutting the standard case for innatism. And, second, he presents a series of reasons for thinking that innatism is not only rationally unsupported, but false. I turn now to representative examples of each stage of his polemic against innatism.

\subsection{Undercutting the Case for Innatism.}

Locke defines innatism as the view according to which "there are in the understanding certain

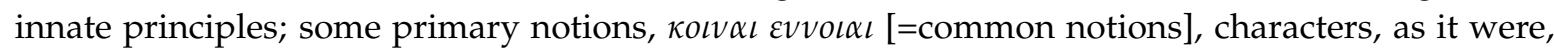
stamped upon the mind of man, which the soul receives in its very first being; and brings into the world with it" ([21], I.ii.1). As he sees it, the typical case for innatism goes roughly as follow:

There is nothing more commonly taken for granted, than that there are certain principles, both speculative and practical...universally agreed upon by all mankind: which therefore, they argue, must needs be constant impressions, which the souls of men receive in their first beings, and which they bring into the world with them, as necessarily and really as they do any of their inherent faculties ([21], I.ii.2).

We can formalize this argument-what we can call the argument from universal agreement for innatism-in the following way:

(U1) There are certain principles, $P_{1} \ldots P_{n}$, universally agreed to by all mankind. [=universality thesis]

(U2) If $P$ is the focus of universal agreement, then $P$ is innate. [=implication thesis]

(U3) Thus, $P_{1} \ldots P_{n}$ are innate. [from U1 and U2]

The similarities between the argument Locke recites here and Calvin's argument from universal possession are easy enough for students to spot. Both are comprised of an empirical claim about universality, together with a claim about what that universality supposedly implies. We could nitpick a bit more, to be sure: for Calvin, the relevant universality is the possession of an idea/awareness/conviction/belief, whereas for Locke the relevant universality pertains to assent to a proposition. Additionally, the arguments differ with respect to the scope of the implication thesis: while Calvin's is focused restrictedly on the universality (and hence innateness) of the sensus in particular, the argument Locke recites captures a more generalized case for innatism. At any rate, given the structural parallels between the two arguments, strikes against U1-U3 will on most occasions double as strikes against $\mathrm{C} 1-\mathrm{C} 4$.

Locke rejects both premises of the argument from universal agreement. Starting with premise $\mathrm{U} 2$, he reasons as follows: Even if one were to grant that there are propositions to which everyone assents (like, say, the principle of non-contradiction or the proposition "there is a God"), that universal agreement alone would not be enough to entail the innateness of the propositions in question, precisely because we would have other (and, Locke thinks, tidier) explanations for such universality. For example, those propositions could have been taught to children by their earliest caretakers or, more generally, by the customs of society, which Locke depicts as "a greater power than nature, seldom failing to make them worship for divine what she hath inured them to bow their minds [to]" ([21], I.iii.25). Alternatively, the universal agreement in question could stem from the fact that the truth-value of the proposition in question is simply self-evident in the sense that the mind is able to directly perceive the agreement (or, disagreement) between the constituent ideas without the aid of any intermediate ideas-and not in the least because the principle is innate ([21], IV.ii.1; [19], p. 46). Accordingly, insofar

3 In general, my approach to Locke's response to innatism follows [19]. My discussion is also informed by [20]. 
as universal agreement would be explainable by appeal to things other than innateness, premise U2 is certainly problematic, in which case the argument from universal consent is, at least as worded above, unsound.

Locke also rejects premise U1: “there are none [principles] to which all mankind give an universal assent" ([21], I.ii.4). His reasoning is that if any principle has a shot at soliciting universal assent, it would have to be something as elementary as, say, the principle of identity (viz., "whatsoever is, is") or the principle of non-contradiction. But, alas, children and idiots do not even perceive those principles in their minds ([21], I.ii.5). And, in Locke's view, if children and idiots do not perceive those principles in their minds, then they surely cannot understand them or, in turn, assent to them. Accordingly, even the most plausible candidates for universal agreement fail to garner universal assent.

Such a critique of the argument from universal agreement might strike undergraduates as utterly fatal, were we to ignore Locke's contentious assumption that an idea or proposition could not possibly be imprinted in a mind if it is not (or, at least, was not) consciously perceived by that mind (at some point). But of course the savvier proponent of innatism will inevitably want to punch back here: the point is not that every human mind (occurrently) perceives actual ideas and principles ab initio, but rather that every human mind has an innate potential or capacity or disposition to perceive (and, hence, assent to) those ideas and propositions under this or that condition. Accordingly, once we trade in occurrent innatism for its more sophisticated dispositional cousin-and once we properly qualify the universality and implication theses to specify the relevant conditions under which these ideas and principles would indeed be perceived and agreed to by the mind-the argument from universal agreement can stand firm against Locke's attack on premise U1. Or so Locke's savvy innatist opponent might argue.

Now, it is worth noting that many of Calvin's interpreters read him as endorsing precisely this sort of dispositional variety of innatism, as opposed to an occurrent variety, which is a point to which I return below. For now, though, consider how a dispositional account of innatism might run. As William Uzgalis observes, the dispositional innatist could insist that

innate propositions are capable of being perceived under certain circumstances. Until these circumstances come about the propositions remain unperceived in the mind. With the advent of these conditions, the propositions are then perceived ([22], sect. 2.1).

To his credit, Locke considers a range of the disposition-actualization conditions to which his dispositional innatist opponent might turn. Dispositional innatists might claim, for example, that the mind perceives, and hence assents to, the relevant principles ...

[a] ... "as soon as men come to the use of reason" ([21], I.ii.7); or

[b] ... when the use of reason "assists them in the discovery of the ideas and principles" ([21], I.ii.7); or

[c] ... as soon as the proposition is proposed and all the terms involved are understood ([21], I.ii.17).

As Locke sees it, though, none of those qualifications to the universality thesis and the implication thesis will work to vindicate innatism. For example, with respect to condition-[a], Locke claims that it is simply "false and frivolous" to say that everyone assents to certain propositions (e.g., the principle of non-contradiction) at the very moment of being endowed with reason ([21], I.ii.12). Observation simply begs to differ.

Suppose, then, we try to qualify the universality thesis and the implication thesis with condition-[b]. Locke's response: if a proposition were to count as innate insofar as it is discovered by reason, then every proposition that is discoverable by reason-including complicated mathematical theorems, for example-would get to count as innate, which Locke thinks is simply ludicrous (though, of course, dispositional innatists might very well want to disagree on this point!).

Or, lastly, suppose we say, with proponents of condition-[c], that an idea is innate just as long as it is assented to upon being heard and properly understood. Locke contends that this particular criterion of innateness gives rise to counterexamples. Samuel Rickless explains one such counterexample as follows: 
...it is plain that the proposition that yellow is not red is assented to as soon as it is proposed and its constituent terms are understood. Hence, [according to the criterion in question], this proposition is innate. Yet the ideas of yellow and red are acquired through sense perception, and so are not innate ([19], p. 51).

The problem here, of course, is that the innateness criterion in question seems to give rise to an unacceptable absurdity: given this innateness criterion, the proposition in question ("yellow is not red") would be at once innate and not innate. So, for Locke, condition-[c] is out.

Ultimately, then, Locke finds both premises of the argument from universal agreement problematic. And if Locke is right to reject the argument from universal agreement as unsound, the proponent of innatism-as well as the proponent of Calvin's sensus-lacks a clear case in support of her views. Admittedly, even if one cannot articulate the putative case for innatism, that alone would not entail that innatism—or Calvin's account of the innate sensus-is false, just rationally unsupported. But Locke is not done yet; enter his rebutting case against innatism.

\subsection{Rebutting Innatism}

In addition to critiquing the standard case for innatism, Locke offers several reasons to think that innatism is simply false ${ }^{4}$. For starters, Locke thinks that the simple fact that there are no propositions that actually enjoy universal assent not only does the work of undercutting the argument from universal consent, but it also effectively doubles as a falsification of innatism. This is because, as he says, "I agree with these defenders of innate principles, that if they are innate, they must needs have universal assent" ([21], I.ii.24). And since there are no principles to which all agree, by modus tollens, there are no innate ones, either.

Of course, we should bear in mind that this sort of rebuttal loses its teeth if we substitute a dispositional analysis of innatism for an occurrent version of it. But suppose we leave that issue to the side for the moment, though. Locke offers a separate rebutting defeater to innatism. With respect to practical principles (e.g., "it is wrong to murder"), there are several reasons for thinking that they are not innate, according to Locke. First, if they were truly stamped on the human heart innately, those principles would have to be self-evident; and they certainly are not self-evident-all practical principles stand in need of argument, he says. Second, if practical principles were actually innate, then there would be no way humans could so easily transgress them with such "confidence and serenity" ([21], I.iii.9). But, sadly, "Robberies, murders, rapes, are the sports of men," Locke says, which is the opposite of what we would expect if moral principles were stamped on the human heart at birth ([21], I.iii.9). Additionally, he argues that, if there were truly innate practical principles on the human mind, we should expect that someone would have already catalogued what those principles are supposed to be ([21], I.iii.14). But, unfortunately, no such catalogue exists.

Locke's ultimate swipe at innatism can be reconstructed in terms of the following argument:

(L1) If the ideas that make up putatively innate principles are themselves not innate, then the principles in question could not be innate.

(L2) The ideas that make up putatively innate principles (including the idea of God) are not innate.

(L3) Thus, the principles in question (including those involving the idea of God) could not be innate. [from L1 and L2]

4 For an excellent and extensive survey of Locke's rebutting arguments against innatism, see ([19], pp. 52-59). My discussion takes several cues from [19], but for the sake of brevity, I focus solely on those considerations that I think are most relevant to the matter at hand. 
Locke focuses his energy on defending premise L2. His approach is to identify those speculative and practical principles that are most frequently cited as being innate and then demonstrate how the ideas that constitute those principles are, in fact, not innate.

It is at this juncture where students can extract from Locke what may be most relevant as a possible rebutting defeater to Calvin's account of the sensus. Locke concedes that "if any idea can be imagined innate, the idea of God may, of all others, for many reasons be thought so" ([21], I.iv.8). But, unlike Calvin, he thinks there are multiple reasons for thinking that the idea of God in particular is simply not innate.

First, Locke contends that, in observing newborns, we simply gather no evidence that they have any ideas (including the idea of God) that would make up the putatively universally assented to principles (including the proposition 'there is a God') ([21], I.iv.2). He writes, for example:

How late is it before any such notion [of God] is discoverable in children? And when we find it there, how much more does it resemble the opinion and notion of the teacher, than represent the true God ([21], I.iv.13).

Second, if the idea of God were innate, it would have to be an idea everyone possessed. But, pace Calvin's appeal to Ciceronian anthropology, Locke thinks there is plenty of evidence that the idea of God is not-and never has been-universally possessed. He notes atheists from antiquity and cites a litany of navigational reports in his own day of whole nations-both civilized and "uncultivated" - that "want the idea and knowledge of God altogether" ([21], I.iv.8). Note that we again see on display Locke's assumption that a mind does not possess an idea of something if it does not occurently perceive the idea in question. Again, though, leave that problem to the side for now.

Third, even among those who have some idea of God, there is little to no consistency in their conception of it, except in name only ([21], I.iv.14-15). What is more, even if the idea of God were universally possessed and consistently conceived, it does not follow from that alone that the idea is innate any more than it would that the idea of fire is innate: the idea of God, like the idea of fire, could be easily acquired a posteriori, spread far and wide, and passed down through the generations ([21], I.iv.9-11).

Fourth, for Locke, the innateness of the idea of God is simply unnecessary for God's goodness in light of what he regards, for example, as perfectly successful inferential approaches for doing natural theology. He says, for example:

Nor do I see how it derogates more from the goodness of God, that he has given us minds unfurnished with these ideas of himself, than that he hath sent us into the world with bodies unclothed, and that there is no art or skill born with us: for, being fitted with faculties to attain these, it is want of industry and consideration in us, and not of bounty in him, if we have them not. It is as certain that there is a God, as that the opposite angles, made by the intersection of two straight lines, are equal ([21], I.iv.16).

And, lastly, Locke contends that if God were to have implanted some idea of God in the human mind, then "it is most reasonable to expect it should have been some clear and uniform idea of himself" ([21], I.iv.17). What we see instead are unclear and non-uniform (or, simply unperceived or nonpossessed) ideas of God, which Locke thinks amounts to evidence against the idea's innateness.

The bottom line here is that, given the many reasons in support of premise L2, and in combination with premise L1, it appears that we have a positive case for thinking innatism is not only rationally unwarranted, but false.

\section{Is Locke's Case against Calvin Decisive?}

Students will inevitably wonder where this side-by-side reading of Calvin and Locke takes us. What damage, if any, does Locke do to Calvin? Has Locke undermined Calvin's argument from universal awareness, for example? And, beyond that, has Locke given us reasons for rejecting the thought humans have an innate sensus? 
How we answer those questions will inevitably depend, at least in part, on whether we read Calvin as an occurrent innatist or a dispositional innatist. For example, if Calvin means to be saying that the sensus is occurrently innate, then by nearly any measure Locke's critique of innatism has indeed laid waste to Calvin's sensus.

That said, as noted above, many of Calvin's interpreters read him as endorsing a dispositional variety of innatism. Michael Sudduth notes, for example, that

Reformed theologians have typically denied that this knowledge [of God] is conscious or occurrent knowledge impressed on the mind from the time of birth. It is best construed as an innate disposition, present from birth, to form a belief in God in a spontaneous manner upon mental maturation and experience of the world ([2], p. 57).

Plantinga, to take one very notable example of this Reformed approach, reads Calvin as asserting merely that "God has implanted in us all an innate tendency, or nisus, or disposition to believe in him," which Plantinga further depicts as a "strong propensity or inclination towards belief" that gets "triggered or actuated by widely realized conditions" ([4], pp. 51-52). Even more recently, Plantinga has interpreted Calvin as saying that, from birth, we have the capacity for knowledge of God-not actual knowledge ([23], p. 173). Along similar lines, Paul Helm construes Calvin's sensus as a "human faculty or disposition to interpret certain data in certain ways," in combination with "what the sensus [qua faculty] senses" ([12], p. 91)

What difference does this sort of interpretative difference make? Helm goes as far to say that Calvin's treatment of the sensus (when understood as a faculty or disposition) is ultimately able to withstand, and even embrace, Locke's attack on innatism. Helm writes, for example:

[I]t is not accurate to say that Calvin's account of the [sensus divinitatis] is of an innate idea of God. He is not committed to the position that all men and women are born with a fully-formed concept of God. Had he known of John Locke's critique of innate ideas, including the innate idea of God, Calvin could or would have concurred ([12], p. 94; emphasis added).

Presumably, the thought here is that, to the extent that Calvin was talking only about innate dispositions or inclinations-as opposed to innate occurrent ideas or knowledge-nothing in Locke's polemic against innatism deals a deathblow against the innateness of the sensus. For example, if Helm is right, Locke presents us with no decisive reason for rejecting premise $\mathrm{U} 1$ as false-nor has he succeeded in rebutting innatism. Or so one might say.

But there are at least two general points worth considering in response to Helm on this matter. The first is this: even if we interpret Calvin as a dispositional innatist, it is not as though Locke's critique of innatism somehow leaves Calvin's account utterly untouched. Suppose we grant, for instance, that Calvin claims only that the sensus is a universally possessed innate disposition to form beliefs about God in such-and-such conditions. But even if Calvin's brand of innatism is strictly dispositional in nature, Locke has still, at a minimum, shifted the burden of proof back on the proponent of Calvin's argument from universal possession. A full defense of that argument against Locke's critique would require its proponents to: [a] offer an account of the specific conditions under which the sensus is actuated such that its output can be perceived by the mind; [b] offer a reason for thinking that such a disposition is universally possessed in the first place; [c] offer a reason for thinking that the universality of such a disposition is best explained by innateness; and [d] explain why the innateness of this disposition is needed as an alternative to inferential approaches to natural theology. Admittedly, another option available to proponents of Calvin's sensus would be to present a completely different case for the innateness of the disposition in question than the argument from universal possession. But that would push us well beyond Calvin, so it seems.

In any case, the burden of proof would not end there. In addition to needing a positive case for the innateness of the sensus (qua disposition), proponents of Calvin's sensus would need to defend against the rebutting considerations Locke offers. And as Rickless rightly observes, dispositional 
innatism might be resilient to some aspects of Locke's rebuttal, but it is not somehow immune to them all ([19], p. 64) - e.g., Locke's point that the innateness of the idea of God is unnecessary for God's goodness in view of successful inferential approaches to natural theology or Locke's worry that, if the idea of God were innate, it should be an idea that is clear to every mind. So even if we insist on viewing Calvin's innatism through dispositional lenses, so to speak, more work would be needed to defend that account against the sort of worries Locke raises. To be sure, developing and defending such a dispositional innatism may very well pay dividends in the long run for religious epistemology, for instance: perhaps dispositional innatism is the right way to think about the grounding of religious faith, especially in light of some of the hurdles facing the standard arguments of natural theology. So, at the least, one of the possible benefits of dispositional innatism is that it potentially leaves more arrows in the quiver of religious apologetics.

That said, still another difficulty remains for Calvin's interpreters, and this brings me to the second general point in response to Helm: it is far from obvious that Calvin actually endorses a dispositional variety of innatism in the first place such that his account of the sensus can simply skirt (much of) Locke's critique of (occurrent) innatism. Readers can surely be forgiven if they find it strange that Calvin's sensus is described by some of his interpreters in terms of an innate capacity or a faculty or a disposition, especially when Calvin himself seems to depicts it fairly straightforwardly as an idea, an awareness, a conviction, a belief. Are each of those terms somehow analyzable as dispositions or capacities or inclinations? Perhaps so, but that is far from obvious.

Part of the problem here may be that Calvin was himself simply unclear on the matter. Wolterstorff admits, for example, that Calvin "was not entirely consistent in his view as to the structure of that indigenous seed of religion: sometimes he thought of it as the innate belief in the existence of a creating and obligating God; rather more often he thought of it as the innate disposition" ([24], p. 165). And even Plantinga, who reads Calvin as a dispositional innatist, acknowledges in a footnote to his discussion of the sensus that "Calvin interpretation is not my project here" and, further, that he concedes that it can sometimes "sound as if Calvin thinks knowledge of God is innate, such that one has it from birth" ([23], p. 172, n 7; [23], p. 173). All the same, Plantinga surmises, "My guess is Calvin thinks...what one has from one's mother's womb is not this knowledge of God; but a capacity for it. Whatever Calvin thinks, however, it's our model" ([23], p. 173; emphasis added).

Other interpreters are neither as quick nor as confident in attributing-or imparting-a dispositional variety of innatism to Calvin. Commenting on Plantinga's interpretation of Calvin in particular, Sudduth writes: "I would argue in response to this increasingly prevalent interpretation of Calvin that, despite its philosophical plausibility, it is-as an interpretation of Calvin-somewhat misleading" ([25], pp. 59-60; emphasis added). Sudduth points out, for example, that

Calvin is quite emphatic about the 'sense of divinity...engraved upon men's minds' as constituting knowledge of God. The sensus divinitatis is not a mere disposition or belief-forming mechanism that is innate, but the knowledge itself is innate ([25], p. 60; emphases added).

Similarly, Adams argues that the sensus for Calvin "is not simply a gut-feeling, intuition or vague impression, but a cognition, an intellectual consciousness of God the creator" ([11], p. 284).

At a minimum, then, it is fair to say that serious debate remains as to how we should interpret Calvin on the matter: despite whether construing the sensus as an innate disposition is a charitable interpretation of the sensus, it is not obvious whether this amounts to an interpretation of Calvin that is allowable by the text. That means there is much to discuss regarding whether Locke's polemic against innatism, in the end, poses a fatal threat to Calvin's treatment of the sensus. And in view of those disputes, several significant philosophical and theological questions remain. Are we born blank slates-and blank in what respect? Could knowledge of God's existence be the natural output of a properly functioning human mind when confronted with the conditions that activate an innate disposition to believe? Or is knowledge of God's existence acquired only by means of an inference from 
more basic beliefs? What is the nature of that inference, and what are we to say if no such inference seems convincing in light of the objections?

It remains, as it always does, for students to wrestle with these issues for themselves. My hope is that the foregoing helps to move that inquiry along in fruitful ways.

Acknowledgments: For helpful comments on a previous draft of this paper, the author thanks the attendees of his paper session at the "Teaching the Christian Intellectual Tradition" Conference on the Reformations (Samford University, Birmingham, AL, USA, 6-8 October 2016).

Conflicts of Interest: The author declares no conflict of interest.

\section{References and Notes}

1. Emil Brunner, and Karl Barth. Natural Theology: Comprising "Nature and Grace" by Professor Dr. Emil Brunner and the Reply "No!" by Dr. Karl Barth. Eugene: Wipf and Stock, 2002.

2. Michael Sudduth. The Reformed Objection to Natural Theology. Burlington: Ashgate, 2009.

3. Nicholas Wolterstoff. "Introduction." In Faith and Rationality: Reason and Belief in God. Edited by Alvin Plantinga and Nicholas Wolterstorff. Notre Dame: University of Notre Dame Press, 1983.

4. Alvin Plantinga. "The Reformed Objection to Natural Theology." Proceedings of the American Catholic Philosophical Association 15 (1980): 49-63. [CrossRef]

5. Michael Sudduth. "Revisiting the 'Reformed Objection' to Natural Theology." European Journal for Philosophy of Religion 2 (2009): 37-62.

6. Thomas A. Woolford. "Natural Theology and Natural Philosophy in the Late Renaissance." Ph.D. Thesis, Trinity College, University of Cambridge, Cambridgeshire, UK, November 2011.

7. John Calvin. Commentaries on the Epistle of Paul the Apostle to the Romans. Edited and translated by John Owen. Grand Rapids: Christian Classics Ethereal Library, n.d. Available online: http://www.ccel.org/ccel/calvin/ calcom38.pdf (accessed on 16 September 2016).

8. John Locke. "A Paraphrase and Notes on the Epistle of St. Paul to the Romans." In The Works of John Locke in Nine Volumes, 12th ed. London: Rivington, 1824, vol. 7, Sects. II and III; Available online: http://oll.libertyfund.org/titles/locke-the-works-vol-7-essays-and-notes-on-st-pauls-epistles (accessed on 16 September 2016).

9. John Calvin. The Institutes of the Christian Religion. Translated by Henry Beveridge. Grand Rapids: Christian Classics Ethereal Library, n.d. Available online: http://www.ccel.org/ccel/calvin/institutes/ (accessed on 16 September 2016). All references to this text above cite book, chapter, and section numbers.

10. John Calvin. The Institutes of the Christian Religion. Edited by John T. McNeil. Translated and indexed by Ford Lewis Battles. Philadelphia: The Westminster Press, 1960. All references to this text above cite book, chapter, and section numbers.

11. Edward Adams. "Calvin's View of Natural Knowledge of God." International Journal of Systematic Theology 3 (2001): 280-92. [CrossRef]

12. Paul Helm. "John Calvin, the Sensus Divinitatis, and the Noetic Effects of Sin." International Journal for Philosophy of Religion 43 (1998): 87-107. [CrossRef]

13. Egil Grilis. "Calvin's Use of Cicero in the Institutes I:1-5: A Case Study in Theological Method." Archiv fur Reformationsgeschichte 62 (1971): 5-37. [CrossRef]

14. Marcus Tullius Cicero. De Natura Deorum (On the Nature of the Gods). Translated by Francis Brooks. London: Methuen, 1896. Available online: http:oll.libertyfund.org/titles/539 (accessed on 16 September 2016).

15. Nicholas Jolley. Locke: His Philosophical Thought. New York: Oxford University Press, 1999.

16. Richard Ashcraft. "Faith and Knowledge in Locke's Philosophy." In John Locke: Problems and Perspective. Edited by John W. Yolton. New York: Cambridge University Press, 1969, pp. 194-223.

17. Victor Nuovo. "Locke's Christology as a Key to Understanding his Philosophy." In The Philosophy of John Locke: New Perspectives. Edited by Peter R. Antsey. New York: Routledge, 2003, pp. 129-53, (esp. at p. 141).

18. John W. Yolton. Locke: An Introduction. New York: Basil Blackwell, 1985.

19. Samuel Rickless. "Locke's Polemic against Nativism." In The Cambridge Companion to Locke's "Essay Concerning Human Understanding." Edited by Lex Newman. New York: Cambridge University Press. pp. 33-66.

20. Jeffrey Tlumak. Classical Modern Philosophy: A Contemporary Introduction. New York: Routledge, 2007. 
21. John Locke. “An Essay concerning Human Understanding, Part 1.” In The Works of John Locke, in Nine Volumes, 12th ed. London: Rivington, 1824, vol. 1. Available online: http://oll.libertyfund.org/titles/761 (accessed 16 September 2016). All references to this text above cite book, chapter, and section numbers.

22. William Uzgalis. "John Locke." In The Stanford Encyclopedia of Philosophy, 2016. Available online: http: / / plato.stanford.edu/archives/spr2016/entries/locke/ (accessed on 6 June 2016).

23. Alvin Plantinga. Warranted Christian Belief. New York: Oxford University Press, 2000.

24. Nicholas Wolterstorff. “The Reformed Tradition." In A Companion to Philosophy of Religion. Edited by Philip L. Quinn and Charles Taliaferro. Malden: Blackwell, 1999, pp. 165-70.

25. Michael L. Czapkay Sudduth. "The Prospects for 'Mediate' Natural Theology in John Calvin." Religious Studies 31 (1995): 43-68. [CrossRef]

(C) 2017 by the author; licensee MDPI, Basel, Switzerland. This article is an open access article distributed under the terms and conditions of the Creative Commons Attribution (CC BY) license (http:/ / creativecommons.org/licenses/by/4.0/). 